Acta vet. scand. $1971,12,536-550$.

From the Department of Medicine II, Royal Veterinary College, Stockholm, Sweden.

\title{
THE EFFECT OF CYCLIC ADENOSINE 3', 5' MONOPHOSPHATE, METHYL XANTHINES AND NICOTINIC ACID ON PLASMA NONESTERIFIED FATTY ACIDS IN SHEEP
}

By

Jan Luthman and Gösta Jonson

Cyclic adenosine $3^{\prime}, 5^{\prime}$ monophosphate (3', 5' AMP) plays a key role in the regulation of several cellular processes (Robison et al. 1968). Lipolysis in adipose tissue is one of the metabolic processes which is regulated by the intracellular level of $3^{\prime}, 5^{\prime}$ AMP. Cyclic AMP is synthetized from adenosine triphosphate (ATP) in a reaction which requires magnesium and which is catalyzed by a specific enzyme, adenyl cyclase (Sutherland et al. 1962). The inactivation by hydrolysis to adenosine $5^{\prime}$ monophosphate ( $5^{\prime}$ AMP), is catalyzed by a specific phosphodiesterase (Butcher \& Sutherland 1962). The intracellular level of 3', 5' AMP is thus dependent on the activity of at least two enzyme systems. A number of lipolytic hormones have been shown to increase the intracellular level of $3^{\prime}, 5^{\prime}$ AMP in the fat cell (Butcher et al. 1968). Increased levels of $3^{\prime} 5^{\prime}$ AMP lead to activation of a triglyceride lipase, which initiates the hydrolysis of triglycerides to glycerol and fatty acids (Rizak 1964, Steinberg 1966). It was further shown by Butcher \& Sutherland that 3', 5' AMP phosphodiesterase was inhibited by methyl xanthines, of which theophylline was much more potent than caffeine and theobromine. Butcher et al. also found that caffeine acted synergistically with lipolytic hormones in the formation of $3^{\prime}, 5^{\prime}$ AMP. Since it seemed unlikely that caffeine and hormones acted 
on the same enzyme system, it was assumed that the hormones affected the adenyl cyclase system. Direct evidence for this hypothesis was presented by Vaughan \& Murad (1969).

The antilipolytic effect of nicotinic acid was discovered by Carlson \& Orö (1962). Since then the antilipolytic effect of nicotinic acid has been studied both in vivo and in vitro by a number of investigators, e. g. Carlson (1963), Carlson \& Liljedahl (1963), Fröberg \& Orö (1963), Bergström \& Carlson (1965), and Nye \& Buchanan (1969).

Butcher \& Baird (1969) stated that it seems clear that the antilipolytic effect of nicotinic acid is due to its ability to lower intracellular 3', 5' AMP levels. Krishna et al. (1966) proposed that nicotinic acid activates phosphodiesterase, but this hypothesis could not be verified by Kupiecki \& Marshall (1968) and Therriault \& Winthers (1970).

While the lipolytic effect of $3^{\prime}, 5^{\prime}$ AMP is well documented in vitro, in vivo studies have shown great irregularities. The metabolic effects of exogenous $3^{\prime}, 5^{\prime}$ AMP have been studied in a number of species including man (Levine \& Vogel 1965, Bergen et al. 1966, Levine \& Lewis 1967, and Levine 1968). In these experiments the glycogenolytic effect of $3^{\prime}, 5^{\prime}$ AMP was easily demonstrated, the intravenous injection was followed by a sharp rise in blood glucose. No significant increase in the plasma concentration of nonesterified fatty acids (NEFA) occurred. If any changes at all occurred, NEFA decreased. This somewhat surprising finding may be explained in several ways. Exogenous $3^{\prime}, 5^{\prime}$ AMP has a very poor ability to penetrate cell membranes and is rapidly inactivated and it may be possible that the phosphorylase system is easier activated than the lipase system. Another factor which may mask or depress a potential weak lipolytic effect of $3^{\prime}, 5^{\prime}$ AMP is hyperglycemia. The role of hyperglycemia as a NEFA depressant factor was first pointed out by Dole (1956) and Gordon \& Cherkes (1956). The increased blood glucose level makes more $\alpha$-glycerophosphate available for reesterification of fatty acids in adipose tissue.

The purpose of the present investigation was to study the lipolytic effect of $3^{\prime}, 5^{\prime}$ AMP in normal sheep and in sheep pretreated with large doses of nicotinic acid. By treatment with nicotinic acid the hyperglycemia following administration of $3^{\prime}, 5^{\prime}$ AMP may be abolished, since it was previously shown that nicotinic acid at a dose of $100 \mathrm{mg} / \mathrm{kg}$ caused a complete depletion 
of liver glycogen (Luthman et al. 1970). The aim was also to study the effect on NEFA of methyl xanthines, nicotinic acid and some related chemicals.

\section{MATERIAL AND METHODS}

Adult female sheep were used in all experiments. Sheep are typical flock animals and are very easily excited. According to our experience blood sampling at frequent intervals by venipuncture was not advisable, since the handling of the animals causes an immediate stress, which is followed by elevated blood glucose and NEFA levels. Therefore only animals trained for blood sampling and kept in individual pens were used, and a plastic cannula (Braunüle $2 \mathrm{R}$, Braun, Melsungen) was inserted in a jugular vein several hours before the experiment. Blood was sampled in heparinized tubes (Heparinrör, Vitrum, Stockholm). If the animals became frightened and excited by some unforeseen reason, the experiment was immediately interrupted.

The effects of the following preparations were studied. Cyclic adenosine $3^{\prime}, 5^{\prime}$ monophosphoric acid, nicotinic acid, pyridyl-3acetic acid, pyridyl-2-acetic acid hydrochloride, theophylline, ethylene diamine theophyllinate (Teofyllamin, $20 \mathrm{mg} / \mathrm{ml}$, ACO, Stockholm, Sweden), caffeine and theobromine. All chemicals except theobromine were dissolved in physiological saline. Because of its insolubility in saline, theobromine was dissolved in a $20 \%$ tribasic sodium phosphate solution. The solution used contained $25 \mathrm{mg}$ theobromine per $\mathrm{ml}$. All chemicals were administered intravenously. Nicotinic acid and pyridyl-3-acetic acid were also administered orally. The effect of $3^{\prime}, 5^{\prime}$ AMP was studied in three normal animals and in two animals pretreated orally with nicotinic acid at a dose of $100 \mathrm{mg} / \mathrm{kg}$. The pretreated animals received 3', 5' AMP 24 hrs. and 48 hrs. after nicotinic acid administration respectively. Starved animals were used only in the experiments where the effect of pyridyl-3-acetic acid and nicotinic acid on caffeine induced lipolysis was studied. All other animals were taken from the flock at various times of the day. NEFA was determined according to Dole (1956) and blood glucose according to the glucose oxidase method of Lundén (1963) (Reagents from AB KABI, Stockholm). Blood for glucose determination was deproteinized with perchloric acid immediately after sampling. Samples for NEFA determination were cooled 


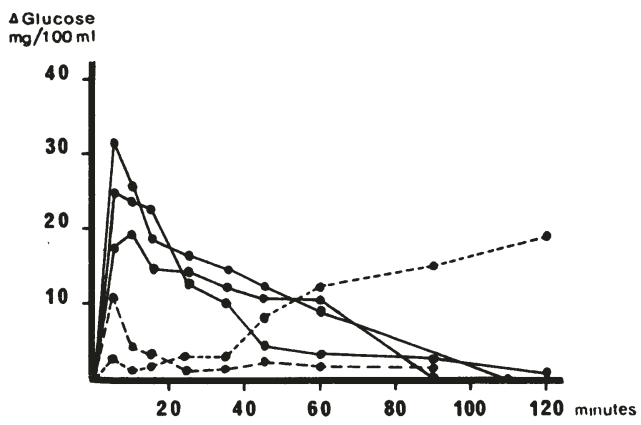

F i g u r e 1. The glucose response to intravenous injection of $10 \mathrm{mg} /$ $\mathrm{kg}$ of 3', 5' AMP in normal animals (—_), and $24 \mathrm{hrs}$. (-.....-) and $48 \mathrm{hrs}$. (_ _ - ) after oral administration of $100 \mathrm{mg} / \mathrm{kg}$ of nicotinic acid.

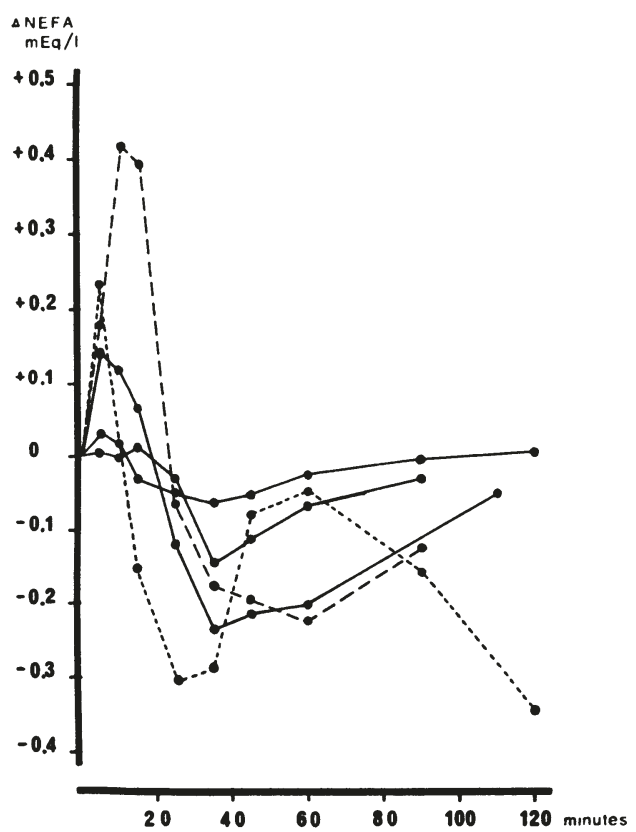

F i g u r e 2. The NEFA response to intravenous injection of $10 \mathrm{mg} /$ $\mathrm{kg}$ of $3^{\prime}, 5^{\prime}$ AMP in normal animals (and $48 \mathrm{hrs}$. (_ - -) after oral administration of $100 \mathrm{mg} / \mathrm{kg}$ of nicotinic acid. 
and plasma was separated as soon as possible. The plasma samples were stored deep frozen until analyzed. No samples were stored longer than three days.

\section{RESULTS}

The intravenous injection of $10 \mathrm{mg} / \mathrm{kg}$ of $3^{\prime}, 5^{\prime}$ AMP was followed by an immediate elevation of blood glucose in all normal animals. In the animals pretreated with nicotinic acid this initial rise in blood glucose was greatly reduced. The animal given nicotinic acid $48 \mathrm{hrs}$. before showed an increase in blood glucose, which started about $30 \mathrm{~min}$. after the injection and remained during the experimental period. The changes in blood glucose in all animals are shown in Fig. 1. The values obtained at zero time were for the normal animals 39,49 and $41 \mathrm{mg} / 100 \mathrm{ml}$, and 24 and $48 \mathrm{hrs}$. after nicotinic acid administration $56 \mathrm{mg} / \mathrm{ml}$ and $73 \mathrm{mg} / \mathrm{ml}$ respectively. The changes in NEFA are shown in Fig. 2. In only one of the normal animals there was a small initial rise in NEFA. After about 10 min. NEFA decreased in all animals and minimum was reached after $35 \mathrm{~min}$. The animals pretreated with nicotinic acid showed an initial increase in NEFA, which
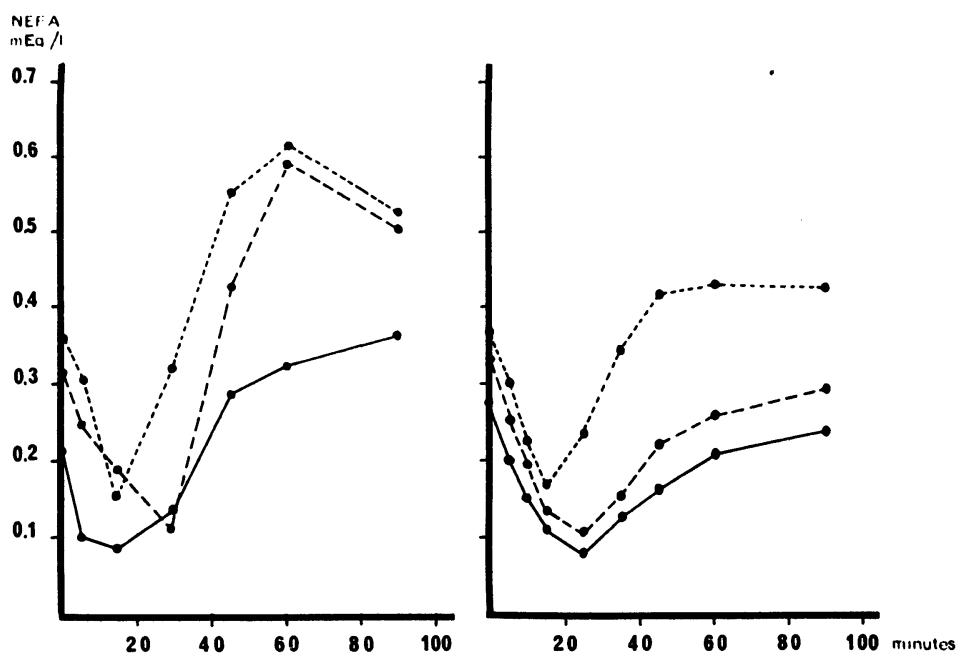

F i g u r e 3. Changes in NEFA following intravenous injection of nicotinic acid (left) and pyridyl-3-acetic acid (right) at doses of $2 \mathrm{mg} /$ $(-\ldots .-), 4 \mathrm{mg} / \mathrm{kg}\left(-_{-}\right)$and $6 \mathrm{mg} / \mathrm{kg}$ (— 


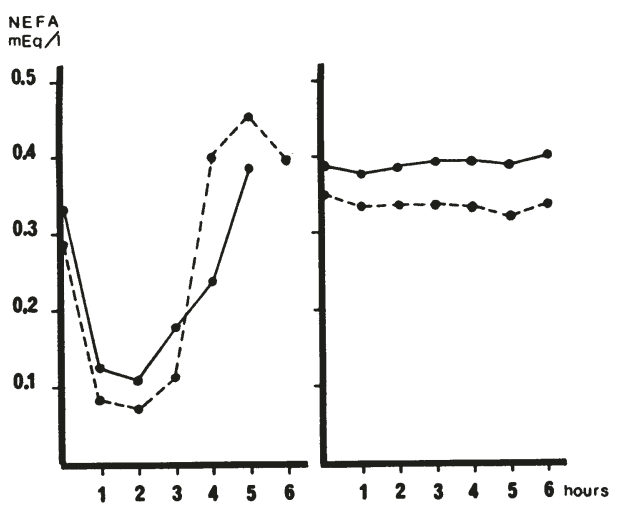

F i g u r e 4.. Changes in NEFA after oral administration of nicotinic acid (left) and pyridyl-3-acetic acid (right) at doses of $50 \mathrm{mg} / \mathrm{kg}$ (———) and $100 \mathrm{mg} / \mathrm{kg}$ (—
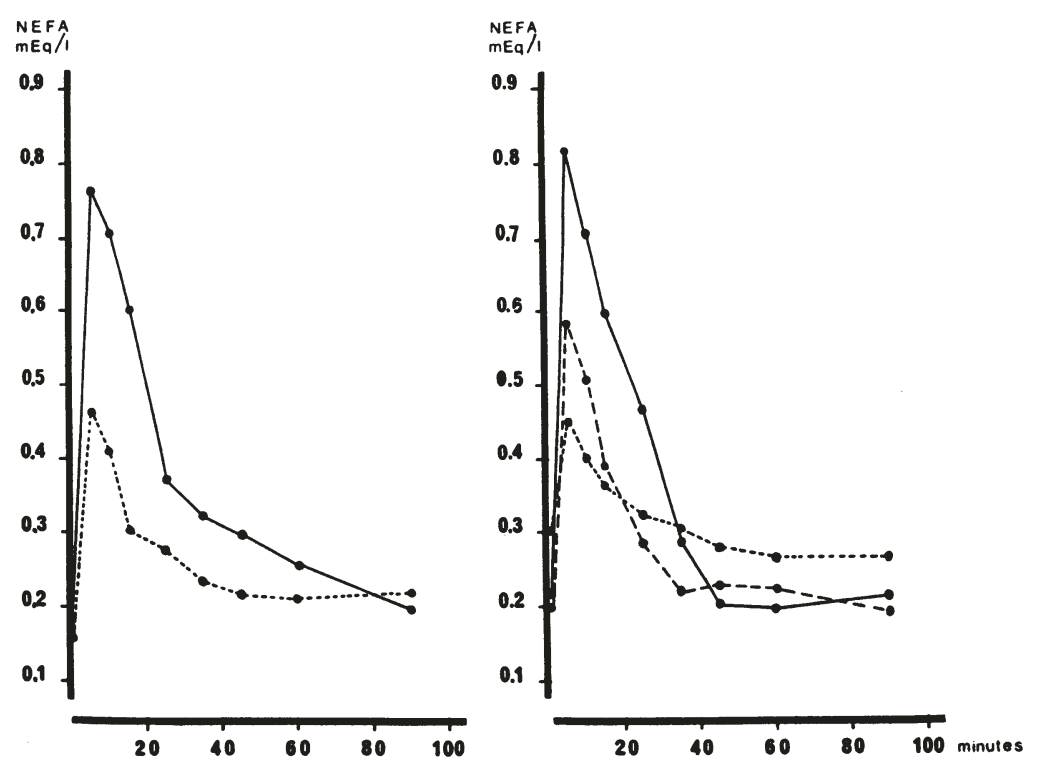

F i g u r e 5. The effect on NEFA of intravenous injection of theophylline (left) and ethylene diamine theophyllinate (right) at doses of $10 \mathrm{mg} / \mathrm{kg}(-\ldots .-)_{1}, 15 \mathrm{mg} / \mathrm{kg}\left({ }_{-}-\right)$and $20 \mathrm{mg} / \mathrm{kg}$ (——). 
was most pronounced in the animal treated $48 \mathrm{hrs}$. before. This animal showed a biphasic NEFA curve. The other pretreated animal showed a triphasic NEFA curve during the course of the experiment. NEFA values at zero time were in the normal animals $0.23,0.40$ and 0.27 meq./l. Twenty-four hrs. after nicotinic acid administration NEFA was 0.62 meq./1. Fig. 3 shows the antilipolytic effect of nicotinic acid and its homologue pyridyl-3acetic acid after intravenous administration. Both substances were used at the same doses, 2,4 and $6 \mathrm{mg} / \mathrm{kg}$. NEFA was depressed in all animals, but in two of the three animals given nicotinic acid there was a rebound elevation of NEFA, and after 60 min. NEFA was about $50 \%$ higher than at zero time. Fig. 4 shows the effect of nicotinic acid and pyridyl-3-acetic acid after oral administration of 50 and $100 \mathrm{mg} / \mathrm{kg}$ of each compound. Nicotinic acid showed a potent antilipolytic activity, while pyridyl-3-acetic acid did not change NEFA. The intravenous injection of theophylline (10 and $20 \mathrm{mg} / \mathrm{kg}$ ) and ethylene diamine theophyllinate $(10,15$ and $20 \mathrm{mg} / \mathrm{kg}$ ) was followed by an immediate rise in NEFA (Fig. 5). Also caffeine showed a potent lipolytic activity at the doses of $10 \mathrm{mg} / \mathrm{kg}$ and $20 \mathrm{mg} / \mathrm{kg}$ (Fig. 6). Nico-

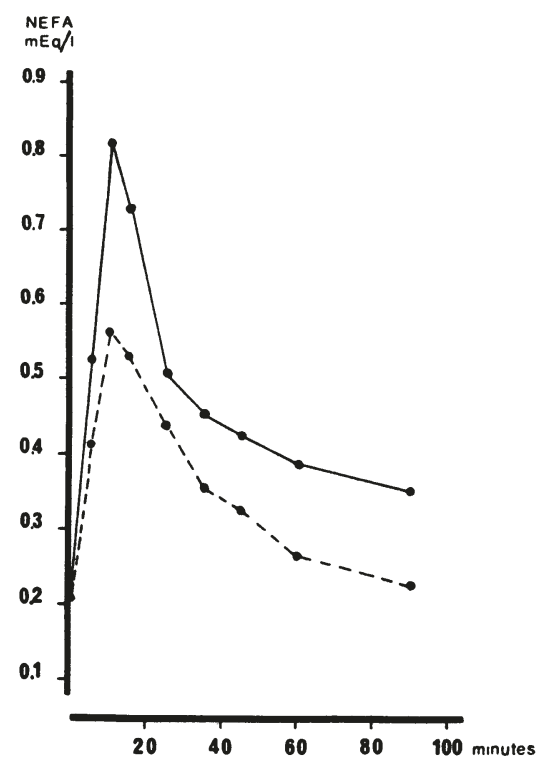

Figure 6. The effect on NEFA after intravenous injection of caffeine $20 \mathrm{mg} / \mathrm{kg} \mathrm{(—)} \mathrm{and} 10 \mathrm{mg} / \mathrm{kg}$ ( $—-)$. 


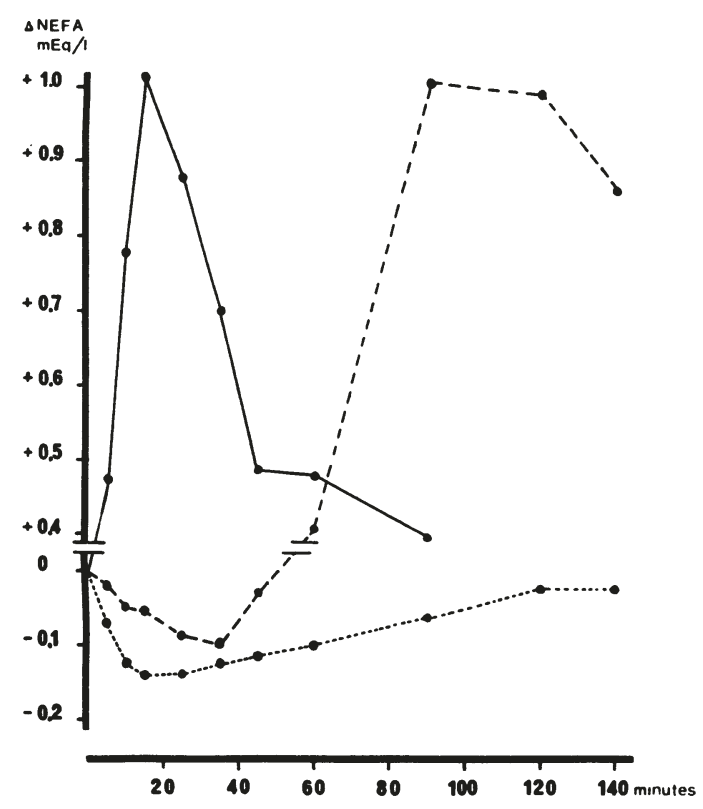

F i g u r e 7. Changes in NEFA after intravenous injection of $20 \mathrm{mg}$ / $\mathrm{kg}$ of caffeine (-), simultaneous injection of $20 \mathrm{mg} / \mathrm{kg}$ of caffeine and $6 \mathrm{mg} / \mathrm{kg}$ of nicotinic acid (- - - ), and simultaneous injection of $20 \mathrm{mg} / \mathrm{kg}$ of caffeine and $6 \mathrm{mg} / \mathrm{kg}$ of pyridyl-3-acetic acid (- - - - -). The NEFA values at zero time were $0.35,0.47$, and $0.50 \mathrm{meq} . / \mathrm{l}$ respectively.

tinic acid and pyridyl-3-acetic acid $(6 \mathrm{mg} / \mathrm{kg})$ completely blocked the lipolytic effect of $20 \mathrm{mg} / \mathrm{kg}$ of caffeine (Fig. 7). But in the case of nicotinic acid, a rise occurred in NEFA after $60 \mathrm{~min}$. and maximum was reached after $80 \mathrm{~min}$. The increase in NEFA was as high as that produced by only caffeine. Pyridyl-2-acetic acid did not change NEFA (Table 1). Theobromine showed no lipolytic effect at a dose of $10 \mathrm{mg} / \mathrm{kg}$. The mean value of NEFA increased after theobromine administration, but the changes were not statistically significant when compared with the phosphate control group. About $30 \mathrm{~min}$. after the theobromine injection the animals appeared drowsy and were standing with closed eyes. The lipolytic effect of theophylline was not influenced by tribasic sodium phosphate. The NEFA values obtained after injection of $20 \mathrm{mg} / \mathrm{kg}$ of theophylline in phosphate were at the same times after administration as in Tables 1 and 2 $0.23,0.83,0.65,0.56,0.35,0.31,0.25,0.27$ and $0.21 \mathrm{meq} . / 1$. 
T a b l e 1. Changes in NEFA (meq./l) after intravenous injection of $10 \mathrm{mg} / \mathrm{kg}$ of pyridyl-2-acetic acid (mean $\pm \mathrm{s}$ ).

\begin{tabular}{|c|c|c|c|c|c|c|c|c|c|}
\hline & \multicolumn{9}{|c|}{ Minutes } \\
\hline & 0 & 5 & 10 & 15 & 25 & 35 & 45 & 60 & 90 \\
\hline $\begin{array}{l}\text { Saline } \\
\text { controls } \\
(n=5)\end{array}$ & $\begin{array}{r}0.22 \\
\pm 0.03\end{array}$ & $\begin{array}{r}0.21 \\
\pm 0.02\end{array}$ & $\begin{array}{r}0.22 \\
\pm 0.02\end{array}$ & $\begin{array}{r}0.23 \\
\pm 0.03\end{array}$ & $\begin{array}{r}0.22 \\
\pm 0.04\end{array}$ & $\begin{array}{r}0.22 \\
\pm 0.02\end{array}$ & $\begin{array}{r}0.23 \\
\pm 0.03\end{array}$ & $\begin{array}{r}0.21 \\
\pm 0.02\end{array}$ & $\begin{array}{r}0.21 \\
\pm 0.03\end{array}$ \\
\hline $\begin{array}{l}\text { Pyridyl- } \\
\text {-2-acetic acid } \\
(n=5)\end{array}$ & $\begin{array}{r}0.27 \\
\pm 0.04\end{array}$ & $\begin{array}{r}0.27 \\
\pm 0.05\end{array}$ & $\begin{array}{r}0.29 \\
\pm 0.03\end{array}$ & $\begin{array}{r}0.27 \\
\pm 0.03\end{array}$ & $\begin{array}{r}0.29 \\
\pm 0.02\end{array}$ & $\begin{array}{r}0.29 \\
\pm 0.05\end{array}$ & $\begin{array}{r}0.29 \\
\pm 0.04\end{array}$ & $\begin{array}{r}0.28 \\
\pm 0.02\end{array}$ & $\begin{array}{r}0.28 \\
\pm 0.02\end{array}$ \\
\hline
\end{tabular}

T a b l e 2. Changes in NEFA (meq./l) after intravenous injection of $10 \mathrm{mg} / \mathrm{kg}$ of theobromine (mean $\pm \mathrm{s}$ ).

\begin{tabular}{|c|c|c|c|c|c|c|c|c|c|}
\hline & \multicolumn{9}{|c|}{ Minutes } \\
\hline & 0 & 5 & 10 & 15 & 25 & 35 & 45 & 60 & 90 \\
\hline $\begin{array}{l}\text { Phosphate } \\
\text { controls } \\
(\mathrm{n}=5)\end{array}$ & $\begin{array}{r}0.21 \\
\pm 0.03\end{array}$ & $\begin{array}{r}0.23 \\
\pm 0.03\end{array}$ & $\begin{array}{r}0.25 \\
\pm 0.05\end{array}$ & $\begin{array}{r}0.24 \\
\pm 0.04\end{array}$ & $\begin{array}{r}0.24 \\
\pm 0.04\end{array}$ & $\begin{array}{r}0.24 \\
\pm 0.02\end{array}$ & $\begin{array}{r}0.23 \\
\pm 0.03\end{array}$ & $\begin{array}{r}0.24 \\
\pm 0.04\end{array}$ & $\begin{array}{r}0.24 \\
\pm 0.04\end{array}$ \\
\hline $\begin{array}{l}\text { Theo- } \\
\text { bromine } \\
(\mathrm{n}=5)\end{array}$ & $\begin{array}{r}0.21 \\
\pm 0.02\end{array}$ & $\begin{array}{r}0.26 \\
\pm 0.03\end{array}$ & $\begin{array}{r}0.29 \\
\pm 0.07\end{array}$ & $\begin{array}{r}0.30 \\
\pm 0.07\end{array}$ & $\begin{array}{r}0.25 \\
\pm 0.05\end{array}$ & $\begin{array}{r}0.20 \\
\pm 0.02\end{array}$ & $\begin{array}{r}0.21 \\
\pm 0.03\end{array}$ & $\begin{array}{r}0.21 \\
\pm 0.03\end{array}$ & $\begin{array}{r}0.22 \\
\pm 0.02\end{array}$ \\
\hline
\end{tabular}

\section{DISCUSSION}

The initial increase in NEFA following $3^{\prime}, 5^{\prime}$ AMP administration was most pronounced in the animals pretreated with nicotinic acid. One of these animals showed a reduced glucose response and in the other animals no initial change in glucose was observed. Liver glycogen was apparently greatly reduced. The experiment clearly demonstrated the glycogenolytic effect of exogenous $3^{\prime}, 5^{\prime}$ AMP. The elevation of blood glucose which started after about $30 \mathrm{~min}$. in one of the pretreated animals was probably caused by increased gluconeogenesis. Increased gluconeogenesis from lactate after $3^{\prime}, 5^{\prime}$ AMP administration was demonstrated by Exton \& Park (1968). The pretreated animals showed higher glucose and NEFA values than the normals at zero time, which may be due to a general stress reaction caused 
by nicotinic acid intoxication. The animals appeared depressed and refused to eat. It was shown previously (Luthman et al. 1970 ) that $100 \mathrm{mg} / \mathrm{kg}$ of nicotinic acid caused moderate degenerative changes in the liver followed by increased serum ornithine carbamyl transferase (OCT) activity.

Since the initial increase in NEFA following $3^{\prime}, 5^{\prime}$ AMP was most pronounced when no hyperglycemia occurred, it seems possible that hyperglycemia depressed the weak lipolytic effect of $3^{\prime}, 5^{\prime}$ AMP. The later decrease in NEFA could, however, not have been caused by increased blood glucose levels, since NEFA decreased in all animals. This decrease in NEFA may be caused either by $3^{\prime}, 5^{\prime}$ AMP itself or by some of the other effects, which it probably induced. There is now evidence that $3^{\prime}, 5^{\prime}$ AMP regulates the release of a number of hormones, which may influence NEFA metabolism, e. g. insulin (Robison et al. 1968), steroids (Levine 1968), thyroid stimulating hormone (Cehovic 1969), growth hormone (Gagliardino \& Martin 1968). The NEFA change following 3', 5' AMP administration is thus a complex response, which may be mediated by several mechanisms.

Nicotinic acid and pyridyl-3-acetic acid showed about the same antilipolytic activity when administered intravenously, while pyridyl-2-acetic acid did not change NEFA. A rebound elevation of NEFA was observed after nicotinic acid but not after pyridyl-3-acetic acid. Pereira (1967) reported that this rebound did not occur in hypophysectomized-adrenalectomized rats and that nicotinic acid caused a significant increase in plasma corticosterone, which was also reported by Johnson \& Kanics (1969). Irie et al. (1967) attributed the rebound phenomenon to increased secretion of growth hormone, but Blackard \& Heidingsfelder (1969) found no relationship between the NEFA rebound and the plasma concentration of growth hormone. Nicotinic acid was effective in depressing NEFA also after oral administration. As was discussed above the higher of the doses used, $100 \mathrm{mg} / \mathrm{kg}$, causes a complete depletion of liver glycogen. Nicotinic acid is synthetized normally in the rumen. The literature in this field was summarized by Hungate (1966). It is, however, uncertain if nicotinic acid occurs in amounts sufficient to influence NEFA metabolism during natural conditions. Pyridyl-3-acetic acid showed no antilipolytic activity when given orally. As the effect was comparable with that of nicotinic acid after intravenous administration, it seems possible that pyridyl-3-acetic acid was 
either not absorbed or was metabolized to inactive metabolites in the rumen or rumen wall.

Caffeine, theophylline and ethylene diamine theophyllinate showed a potent lipolytic effect. Butcher \& Sutherland (1962) reported an equal inhibitory effect on phosphodiesterase activity of theobromine and caffeine, while theophylline was about six times more potent. The results of the in vivo studies in the present investigations are not in accordance with this finding. The lipolytic effect of methyl xanthines in vivo may, however, in part be due to their ability to release catecholamines. Increased urinary excretion of catecholamines after coffee ingestion was reported by Bellet et al. (1969), and Strubelt (1969) presented evidence that endogenous catecholamines were implicated in the hyperglycemic actions of theophylline and caffeine. Theobromine showed no lipolytic effect at a dose of $10 \mathrm{mg} / \mathrm{kg}$. Tribasic sodium phosphate, which was used as solvent, probably did not influence the NEFA response to theobromine, since it did not affect the lipolytic activity of theophylline. About $30 \mathrm{~min}$. after theobromine administration, the animals behaved like after a large dose of a tranquilizing drug and because of this unwanted effect theobromine was not used at higher doses.

Pyridyl-3-acetic acid and nicotinic acid completely blocked the lipolytic effect of caffeine (Fig. 7). This was the only experiment where fasted animals were used. When caffeine and nicotinic acid were given, a late increase in NEFA was observed. Maximum was reached after $90 \mathrm{~min}$. When only nicotinic acid was given, the rebound in NEFA was not so pronounced (Fig. 3). These animals were, however, not fasted. The difference in NEFA rebound was probably caused by the nutritional state of the animals, since Carlson \& Orö (1962) found that the rebound following nicotinic acid was most pronounced in fasted subjects.

Lipolysis is influenced by a number of hormones and chemicals and the results in the present study were to a great extent in conformity with results from in vitro and in vivo studies in other animal species.

\section{REFERENGES}

Bellet, S., L. Roman, O. De Castro, K. E. Kim \& A. Kershbaum: Effect of coffee ingestion on catecholamine release. Metabolism 1969, $18,288-291$. 
Bergen, S. S., J. G. Hilton \& T. B. Van Itallie: Glycogenolytic effect of adenosine 3', 5'-monophosphate in the canine liver. Endocrinology 1966, 79, 1065-1068.

Bergström, S. \& L. A. Carlson: Influence of the nutritional state on the inhibition of lipolysis in adipose tissue by prostaglandin $\mathrm{E}_{1}$ and nicotinic acid. Acta physiol. scand. 1965, 65, 383-384.

Blackard, W. G. \& S. A. Heidingsfelder: Effect of adrenergic receptor blockade on nicotinic acid-induced plasma FFA rebound. Metabolism 1969, 18, 226-233.

Butcher, R. W. \& E. W. Sutherland: Adenosine 3', 5'-phosphate in biological materials. I. Purification and properties of cyclic 3', 5'-nucleotide phosphodiesterase and use of this enzyme to characterize adenosine $3^{\prime}, 5^{\prime}$-phosphate in human urine. J. biol. Chem. 1962, 237, $1244-1250$.

Butcher, R. W. \& C. E. Baird: The regulation of cyclic AMP and lipolysis in adipose tissue by hormones and other agents. In Drugs Affecting Lipid Metabolism, ed. W. L. Holmes, L. A. Carlson \& R. Paoletti. Plenum Press. New York 1969.

Butcher, R. W., C. E. Baird \& E. W. Sutherland: Effects of lipolytic and antilipolytic substances on adenosine $3^{\prime}, 5^{\prime}$-monophosphate levels in isolated fat cells. J. biol. Chem. 1968, 243, 1705-1712.

Carlson, L. A.: Studies on the effect of nicotinic acid on catecholamine stimulated lipolysis in adipose tissue in vitro. Acta med. scand. 1963, 173, 719-722.

Carlson, L. A. \& L. Orö: The effect of nicotinic acid on the plasma free fatty acids. Demonstration of a metabolic type of sympathicolysis. Acta med. scand. 1962, 172, 641-645.

Carlson, L. A. \& S.-O. Liljedahl: Lipid metabolism and trauma. II. Studies on the effect of nicotinic acid or norepinephrine induced fatty liver. Acta med. scand. 1963, 173, 787-791.

Cehovic, G.: Role de l'adenosine 3', 5'-monophosphate - cyclique dans la libération de TSH hypophysaire. (The role of adenosine 3', 5'monophosphate for the release of TSH). C. R. Acad. Sci. (Paris) Série D 1969, 268, 2929—2931.

Dole, V.P.: A relation between non-esterified fatty acid in plasma and the metabolism of glucose. J. clin. Invest. 1956, 35, 150-154.

Exton, J. H. \& C. R. Park: Control of gluconeogenesis in liver. III. Effects of l-lactate, pyruvate, fructose, glucagon, epinephrine and adenosine 3', 5'-monophosphate on gluconeogenic intermediates in the perfused rat liver. J. biol. Chem. 1968, 244, 14241433.

Fröberg, S. \& L. Orö: The effects of nicotinic acid, phentolamine and nethalide on the plasma free fatty acids and the blood pressure in the dog. Acta med. scand. 1963, 127, 635-641.

Gagliardino, J. J. \& J. M. Martin: Stimulation of growth hormone secretion in monkeys by adrenalin, pitressin and adenosine 3', 5'-cyclic monophosphoric acid (3', 5'-AMP). Acta endocr. (Kbh.) 1968, 59, 390-396. 
Gordon, R. S. \& A. Cherkes: Unesterified fatty acid in human blood plasma. J. clin. Invest. 1956, 35, 206-212.

Hungate, $R$. E.: The rumen and its microbes. Academic Press, London and New York 1966.

Irie, M., M. Sakurnu, T. Tsuskima, K. Shizume \& K. Nakato: Effect of nicotinic acid administration on plasma growth hormone concentration. Proc. Soc. exp. Biol. (N.Y.) 1967, 126, 708-711.

Johnson, W. J. \& L. Kanics: Stimulation of adrenocortical secretion by nicotinic acid and certain of its derivates and analogues. Biochem. Med. 1969, 2, 438-447.

Krishna, G., B. Weiss, J. D. Davies \& S. Hynie: Mechanism of nicotinic acid inhibition of hormone induced lipolysis. Fed. Proc. (abstr.) 1966, 25, 719.

Kupiecki, F. P. \& N. B. Marshall: Effects of 5-methyl-pyrazole-3-carboxylic acid (U-19425) and nicotinic acid on lipolysis in vitro and in vivo and on cyclic-3', 5'-AMP phosphodiesterase. J. Pharmacol. exp. Ther. 1968, 168, 166-170.

Levine, R. A.: Effect of exogenous adenosine 3', 5'-monophosphate in man. II. Glucose, nonesterified fatty acid and cortisol responses. Metabolism 1968, 17, 34-45.

Levine, R. A. \& J. A. Vogel: Cardiovascular and metabolic effects of adenosine 3', 5' monophosphate in vivo. Nature (Lond.) 1965, 207, 987-988.

Levine, R. A. \& S. E. Lewis: Hepatic glycogenolytic activity of cyclic 3', 5'-AMP and its monobutyryl derivative. Amer. J. Physiol. 1967, 213, 768-770.

Lundén, R.: Enzymatisk bestämning av glykos. (Enzymatic determination of glucose). Laboratoriet 1963, 1, 1-3 .

Luthman, J., G. Jonson \& P. Holtenius: The preventive effect of nicotinic acid on carbon tetrachloride toxicity in sheep. Acta vet. scand. 1970, 11, 254-267.

Nye, E. R. \& H. Buchanan: Short-term effect of nicotinic acid on plasma level and turnover of free acids in sheep and man. J. Lipid Res. 1969, 10, 193-196.

Pereira, J. N.: The plasma free fatty acid rebound induced by nicotinic acid. J. Lipid Res. 1967, 8, 239-244.

Rizak, M. A.: Activation of an epinephrine-sensitive lipolytic activity from adipose tissue by adenosine $3^{\prime}, 5^{\prime}$-phosphate. J. biol. Chem. 1964, 239, 392-395.

Robison, G. A., R. W. Butcher \& E. W. Sutherland: Cyclic AMP. Ann. Rev. Biochem. 1968, 37, $149-174$.

Steinberg, D.: Catecholamine stimulation of fat mobilization and its metabolic consequences. Pharmacol. Rev. 1966, 18, 217-235.

Strubelt, 0. : The influence of reserpine, propranolol, and adrenal medullectomy on the hyperglycemic actions of theophylline and caffeine. Arch. int. Pharmacodyn. 1969, 179, 215-224. 
Sutherland, E. W., T. W. Rall \& T. Menon: Adenyl cyclase. I. Distribution, preparation and properties. J. biol. Chem. 1962, 237, $1220-1227$.

Therriault, D. G. \& V. G. Winthers: Studies of the effect of nicotinic acid on cyclic nucleotide phosphodiesterase activity in rat heart and adipose tissue. Life Sciences 1970, 9, 421-428.

Vaughan, M. \& F. Murad: Adenyl cyclase activity in particles from fat cells. Biochemistry 1969, 8, 3092-3099.

\section{SUMMARY}

The intravenous injection of $3^{\prime}, 5^{\prime}$ AMP, $10 \mathrm{mg} / \mathrm{kg}$, caused an immediate rise in blood glucose in normal sheep. In sheep where liver glycogen was depleted by pretreatment with $100 \mathrm{mg} / \mathrm{kg}$ of nicotinic acid, the blood glucose response was greatly reduced. The glycogenolytic effect of $3^{\prime}, 5^{\prime}$ AMP was thus easily demonstrated. The injection of $3^{\prime}, 5^{\prime}$ AMP was followed by an immediate rise in NEFA, which was most pronounced in the pretreated animals. After the initial increase there was a fall in NEFA in both the normal and the pretreated animals. The role of hyperglycemia for the NEFA response to exogenous 3', 5' AMP was discussed. It seemed possible that hyperglycemia may modify the initial increase in NEFA. The later fall in NEFA was discussed as a complex response, which may be the result of the action of several hormones, which may be released by $3^{\prime}, 5^{\prime}$ AMP injection. Nicotinic acid and pyridyl-3-acetic acid showed a potent antilipolytic activity. Nicotinic acid caused a rebound elevation of NEFA. No rebound was observed after pyridyl-3-acetic acid. Pyridyl-3-acetic acid, however, did not change NEFA when administered orally. Pyridyl-2acetic acid had no antilipolytic effect. Of the methyl xanthines caffeine and theophylline showed about the same lipolytic activity. Theobromine was quite ineffective.

\section{SAMMANFATTNING}

Effekten av cyklisk $3^{\prime}, 5^{\prime}$ adenosin monofosforsyra, metylxantiner och nikotinsyra på plasmakoncentrationen av icke förestrade fettsyror hos får.

Intravenös injektion av cyklisk $3^{\prime}, 5^{\prime}$ adenosin monofosforsyra (3', 5' AMP) i en dos av $10 \mathrm{mg} / \mathrm{kg}$ gav hos normala får upphov till en omedelbar blodglykosstegring. Hos får, där leverglykogenet reducerats genom förbehandling med nikotinsyra i en dos av $100 \mathrm{mg} / \mathrm{kg}$, uteblev eller reducerades den initiala blodglykosstegringen. Den glykogenolytiska effekten av $3^{\prime}, 5^{\prime}$ AMP kunde således verifieras. Injektionen av $3^{\prime}, 5^{\prime}$ AMP följdes även av en initial ökning av NEFA, vilken var mest uttalad hos de förbehandlade djuren. Efter den initiala stegringen sjönk NEFA hos samtliga djur. Betydelsen av hyperglykämi för NEFA-svaret på exogent tillfört $3^{\prime}, 5^{\prime}$ AMP diskuteras. Det synes möjligt att hyperglykämi kan modifiera den initiala stegringen av NEFA. Den senare 
sänkningen av NEFA diskuteras som ett komplext svar, som kan vara resultatet av effekten av ett flertal hormoner, som frisättes efter tillförsel av 3', 5' AMP. Nikotinsyra och pyridyl-3-ättiksyra hade kraftig antilipolytisk effekt. Nikotinsyra, men ej pyridyl-3-ättiksyra, orsakade en sekundär stegring av NEFA. Pyridyl-3-ättiksyra var helt ineffektiv efter oral tillförsel. Pyridyl-2-ättiksyra hade ingen antilipolytisk effekt. Av metylxantinerna hade koffein och teofyllin ungefär samma lipolytiska effekt. Teobromin hade ingen lipolytisk effekt.

(Received November 16, 1970). 